\title{
PENGARUH INTERVENSI BUAH JAMBU BIJI TERHADAP KADAR KOLETEROL TOTAL PADA ORANG DEWASA DISLIPIDEMIA KOTA KENDARI
}

\author{
Asmarani ${ }^{1}$, Nina Indriyani $\mathbf{N}^{2}$, Rhenislawaty ${ }^{3}$ \\ ${ }^{12}$ Bagian Gizi Fakultas Kedokteran Universitas Halu Oleo Kendari \\ ${ }^{3}$ Bagian Biomedik Fakultas Kedokteran Universitas Halu Oleo Kendari \\ rhanyzahira85@mail.com¹ninaindriyanin@gmail.com² rheni921985@gmail.com ${ }^{3}$
}

\begin{abstract}
Pergeseran pola penyakit di masyarakat yang semula didominasi penyakit menular dan infeksi, saat ini telah beralih ke penyakit degeneratif, misalnya dislipidemia yang merupakan salah satu faktor risiko terjadinya penyakit jantung koroner. Pola makan masyarakat yang tinggi lemak dan kolesterol dapat menyebabkan dislipidemia. Buah yang mengandung serat larut air (pektin), dan vitamin C yang tinggi seperti jambu biji dapat digunakan sebagai bahan intervensi hiperkolesterolemik. Penelitian ini bertujuan Mengetahui pengaruh jambu biji (psidium Guajava) terhadap kolesterol total pada dewasa dislipidemia Kota Kendari. Jenis dan desain penelitian quasi eksperimental. Pada kelompok intervensi diberikan jus jambu biji dan olahraga dan kelompok kontrol berupa olahraga. Subyek mengkonsumsi jambu biji dengan dosis $400 \mathrm{mg}$, sekali sehari dengan volume tiap pemberian $250 \mathrm{ml}$ yang dilakukan selama 30 hari. Sebelum diberikan intervensi tersebut subyek akan diambil darahnya untuk pemeriksaan koleterol total. Jumlah subyek untuk masing-masing kelompok sebesar 33 orang (1:1). Data penelitian yang diambil berupa pengamatan jumlah level lipid darah ( $\mathrm{mg} / \mathrm{dl}$ ) yaitu kolesterol total (TC) dengan menggunaka metode pemeriksaan standar. Data dianalisis menggunakan uji korelasi paired $t$ test. Hasil pada penelitian menunjukkan setelah 4 minggu perlakuan, pemberian jambu biji menurunkan kolesterol total yang signifikan pada kelompok intervensi dibandingkan dengan kelompok kontrol $(p<0,05)$. Kesimpulan penelitian ini Pemberian jus jambu biji terbukti mampu menurunkan kolesterol total.
\end{abstract}

Kata Kunci: jambu biji (Psidium guajava); kolesterol total; dislipidemia

\begin{abstract}
Disease patterns originally dominated by infectious diseases and infections now change to those of degenerative disease, such as dyslipidemia, one of the risk factors for coronary heart disease. In addition, excessive and unhealthy diet gives an effect on the lipid profile. Fruits containing soluble fiber (pectin) and high vitamin C such as guava can be used as material for hypercolesterolamic intervention. On the other hand, mild-moderate exercise also has a clear influence on the decrease of blood lipid profile. The aim of this research is to know the influence of guava (Psidium guajava) and sports on the total cholesterol in dyslipidemia in Kendari. Type of of the research was quasi experimental design. Intervention group were given guava juice and exercise and exercise was only given in control groups. Subjects consumed guava juice at a dose of 400 $\mathrm{mg}$ once daily with a volume of $250 \mathrm{ml}$ each administration, performed for 30 days. Before interventions, blood samples for lipid profile have analyzed. The number of subjects for each group is 33 people (1:1). The data taken in the study are observations of the amount of blood lipid levels $(\mathrm{mg} / \mathrm{dl})$ and total cholesterol (TC) using a standard method. Then, data were analyzed by using tests ofi chi square correlation and Wilcoxon Matched-pairs Signed-rank Test. After 4 weeks of treatment, the intervention significantly decreased the levels of total cholesterol, decreased significantly higher in the intervention group compared to that of the control group $(p<0.05)$. The guava juice is proven to be able to decrease total cholesterol level.
\end{abstract}

Keywords: guava (Psidium guajava); total cholesterol; dyslipidemia 


\section{PENDAHULUAN}

Kecenderungan negara di dunia dalam hal beban penyakit tidak menular (PTM) dan proporsi angka kematian PTM juga terjadi di Indonesia yang ditunjukkan dengan terjadinya peningkatan jumlah penderita PTM dari 41.7 \% di tahun 1995 menjadi $59.5 \%$ di tahun 2007. Penyakit tidak menular meliputi penyakit jantung dan pembuluh darah, diabetes dan penyakit pernapasan kronik ${ }^{1}$.

Menurut data Riset Kesehatan Dasar (Riskesdas) tahun 2013 melaporkan bahwa penyakit jantung koroner berada pada peringkat ke 7 seluruh Indonesia, dan diketahui pula bahwa sebagian masyarakat Indonesia yang berusia diatas 15 tahun telah memiliki kadar total kolesterol, trigliserida dan LDL di atas normal ${ }^{2}$. Data Riskesdas tahun 2013 menunjukkan penyakit jantung koroner di daerah Sulawesi Tenggara berdasarkan wawancara terdiagnosis dokter masih tinggi yakni sebesar 0,4\% di mana rata-rata di Indonesia 0,5\%. Laporan Dinas Kesehatan Provinsi pada tahun 2013 dan 2014 penyakit jantung koroner menduduki peringkat keempat dengan jumlah kasus 24.419 dan 25.4193. Sedangkan dari laporan tahunan di Dinas Kesehatan kota Kendari pada tahun 2014 menunjukkan kasus penyakit jantung koroner menduduki peringkat pertama sebesar $60 \%$ dari 10 penyakit tidak menular terbanyak yang diderita oleh masyarakat kota Kendari ${ }^{4}$.

Faktor penyebab penyakit jantung koroner diantaranya adalah faktor genetik, dislipidemia atau peningkatan fraksi lipid dalam darah obesitas, hipertensi, diabetes mellitus (DM), kurang aktivitas fisik, pola hidup yang tidak sehat, asupan buah dan sayur yang rendah, dan merokok. Dimana dislipidemia menjadi salah satu faktor penyebab terjadinya penyakit jantung koroner pada individu ${ }^{5}$.

Dislipidemia merupakan keadaan kadar kolesterol yang tinggi didalam darah. Di Indonesia prevalensi dislipidemia belum terdata dengan baik, tetapi diketahui prevalensi dislipidemia terus meningkat ${ }^{6}$. Data Survey Kesehatan Rumah Tangga (SKRT) tahun 2004 menyebutkan bahwa prevalensi terjadinya dislipidemia di Indonesia mencapai $14 \%$.

Pola makan masyarakat yang cenderung berlebihan dan tidak sehat berpengaruh pada profil lemak tubuh manusia yang meliputi kolesterol-LDL, kolesterol-HDL, trigliserida dan kolesterol total. Penyempitan pembuluh darah yang mengalirkan darah ke jantung dapat menimbulkan penyakit jantung koroner (PJK) sedangkan penyempitan pembuluh darah arteri ke otak dapat menimbulkan stroke. Stroke dan penyakit jantung koroner erat kaitannya dengan lipid atau lemak. Lemak dan kolesterol tak larut dalam cairan darah oleh karena itu diperlukan lipoprotein sebagai agen transport ${ }^{8}$.

Salah satu tanaman yang memiliki manfaat sebagai penurun kadar kolesterol dalam tubuh adalah jambu biji (Psidium guajava) terutama pada bagian buah jambu biji. Hal ini berkaitan dengan kandungan metabolit sekunder pada jambu biji yaitu pektin, sehingga jambu biji memiliki potensi sebagai anti hiperkolesterolemia herbal. Jambu biji yang dipilih adalah yang berdaging merah, selain karena mudah ditemukan dan kandungan airnya lebih banyak, buah jambu biji ini mengandung vitamin C, likopen, flavanoid dan serat larut air khususnya pektin, serta terdapat tanin yang diduga berfungsi untuk menurunkan kadar kolesterol didalam darah ${ }^{9,10}$.

Berdasarkan permasalahan tersebut penelitian ini dilakukan untuk mengetahui pengaruh intervensi buah jambu biji terhadap kadar koleterol total pada orang dewasa di Kota Kendari.

\section{METODE}

Jenis dan desain penelitian yang akan dilakukan adalah quasi ekperimental bertempat di Kecamatan Kambu, Kadia dan Sodoha, Kota Kendari dan dilakukan selama bulan November 2015. Izin penelitian dan kelaikan etik diperoleh dari Komite Etik Penelitian Kesehatan dan Kedokteran (MHREC) Universitas Gadjah Mada Jumlah subyek 66 orang yang diperoleh melalui rumus sampling untuk penelitian ekperimental.

$$
n=\frac{2 \sigma^{2}[Z(1-\alpha)+Z(1-\beta)]^{2}}{\mu 1-\mu 2^{2}}
$$

$\mathrm{n}=$ besar subyek.

$\alpha=$ standar deviasi

$Z(1-\alpha)=1,64$ (nilai $Z$ untuk tingkat kepercayaan 95\% dimana $\alpha=0,05$ )

$\mathrm{Z}(1-\beta) \quad=1,28$ (nilai $Z$ untuk power $80 \%$ dimana $\beta$ $=0,01$ )

$\mu 1-\mu 2=$ perbedaan rata-rata kadar kolesterol LDL antara kelompok kontrol dan kelompok perlakuan

Berdasarkan perhitungan, diperoleh nilai $n$ minimal 33 subyek untuk masing-masing kelompok. Di awal penelitian subyek yang didapatkan sebanyak 35 orang. Di tengah perjalanan penelitian dua subyek drop out, satu subyek hamil dan satu subyek lainnya mengundurkan diri karena menurut pengakuan subyek mengalami konstipasi selama minum jus jambu. Sehingga di akhir penelitian diperoleh subyek penelitian sebanyak 33 orang pada masing-masing kelompok. 
Subyek adalah laki-laki atau perempuan yang tinggal di wilayah yang telah ditentukan sesuai dengan stratifikasi yang dilakukan, berusia 20-40 tahun, tidak menderita atau belum pernah didiagnosa mengalami gejala penyakit CVD (dislipidemia, hipertensi, jantung, stroke).

Teknik pengumpulan data yang dilakukan dalam penelitian ini menggunakan 33 pasang subyek dislipidemia yang masuk kriteria sebagai berikut: (1) Berusia 20-40 tahun, (2) Kadar kolesterol total tinggi ( $\geq 200 \mathrm{mg} / \mathrm{dL}$ ), (3) Tidak hamil dan menyusui, (4) Tidak merokok, (5) Tinggal di lokasi penelitian, (6) Bersedia menjadi subyek penelitian, dengan menandatangani informed consent.

Subyek diwawancara terkait data diri dan riwayat penyakitnya menggunakan kuesioner karakteristik responden, kemudian dilakukan pengukuran antropometri yang meliputi berat badan, tinggi badan, dan lingkar pinggang. Pengukuran berat badan menggunakan timbangan digital dengan kapasitas 200 kg dengan tingkat ketelitian $0,1 \mathrm{~kg}$, pengukuran tinggi badan dengan menggunakan microtoise kapasitas $200 \mathrm{~cm}$ dengan tingkat ketelitian $0,1 \mathrm{~cm}$, dan pengukuran lingkar pinggang menggunakan pitameter dengan ketelitian $0,1 \mathrm{~cm}$. Setelah itu, responden diwawancara terkait konsumsi energi, konsumsi lemak, konsumsi lemak jenuh, konsumsi kolesterol, dan konsumsi serat menggunakan food recall oleh tenaga enumerator gizi dan peneliti. Selanjutnya, pengambilan subyek pada penelitian ini menggunakan penetapan kolesterol total secara laboratorium yaitu sebelum terapi pasien, berpuasa 10-12 jam dan diukur kolesterol total di laboratorium. Jika pasien memenuhi kriteria, subyek diberikan jus jambu biji selama 30 hari. Setelah pemberian jus jambu selesai maka subyek dipuasakan 10-12 jam kemudian diukur kadar kolesterol total.

Variabel bebas dalam penelitian meliputi jambu biji. Sementara variabel terikat adalah kolesterol total dan variabel luar terdiri dari status gizi parameter (IMT), lingkar pinggang, olahraga, asupan serat, asupan lemak jenuh, asupan kolesterol, asupan energi, dan asupan lemak.

Konsumsi jambu biji adalah rata-rata jumlah serat yang dikonsumsi dalam sehari oleh subyek dalam satuan gram. Tiap sampel diberikan $400 \mathrm{~g}$ jambu biji yang setara dengan 2 buah jambu biji. Diberikan dalam jus sebanyak 1 gelas yang diberikan setiap hari dan diantarkan tiap hari ke rumah masing-masing subyek oleh peneliti dan enumerator. Dalam $100 \mathrm{~g}$ jambu biji terdapat 6,76 g serat $^{11}$.
Olahraga adalah suatu progam aktivitas fisik yang terencana, terstruktur berulang dan memiliki tujuan dalam rangka memperbaiki atau menjaga kesegaran fisik secara objektif yang dikerjakan dilapangan sepak bola di Kecamatan Kambu, Kadia dan Sodoha, Kota Kendari. Lama progam ini adalah 4 minggu. Progam olahraga dilakukan 3 kali seminggu yaitu hari Selasa, Kamis, dan Sabtu pada jam 6 pagi selama@45 menit setiap pertemuan dengan intensitas sedang sampai vigorous. Pemberian olahraga diberikan pada kelompok kontrol dan intervensi. Jenis olahraga yang dilakukan adalah senam aerobic. Diukur dengan nilai METs (Metabolic Equivalent) yakni menilai beban kalori yang dibakar di massa otot perminggu. Dengan rata-rata nilai METs (Metabolic Equivalent) sebesar 7,0 $(6,9 \mathrm{kcal} / \mathrm{kg} / \mathrm{jam})^{12}$. Dipandu oleh instruktur olahraga dari Fakultas ilmu sosial dan politik Universitas Haluoleo. Data dikategorikan menjadi normal jika intensitas latihan 5-7,0 METS atau durasi latihan 15-60 menit, frekuensi 3-5 kali seminggu, rendah jika intensitas latihan < 50 METS atau durasi latihan < 15 menit, frekuensi 1-2 kali seminggu. Satuan variabel dalam bentuk METS.

Status gizi adalah keadaan kesehatan akibat interaksi antara makanan, tubuh manusia, dan lingkungan hidup. Salah satu indikator penilaian status gizi untuk usia dewasa (usia > 18 tahun) adalah menggunakan Indeks Massa Tubuh (IMT) yang diperoleh melalui rumus berat badan (kilogram) dibagi dengan kuadrat tinggi badan (meter), dikategorikan menjadi tidak berisiko, jika IMT $<23,0$ dan berisiko, jika IMT $\geq 23,0^{13}$. Lingkar Pinggang adalah Lingkar pinggang subyek diukur dengan menggunakan pita plastik atau logam di daerah setinggi umbilikus atau pada titik tengah antara tulang iga paling bawah dengan puncak tulang iliaka dengan kriteria sebagai berikut, berisiko, jika pada wanita $\geq 80 \mathrm{~cm}$ dan pada laki-laki $\geq 90$, dan tidak berisiko, jika pada wanita $<80 \mathrm{~cm}$ dan pada laki-laki $<90 \mathrm{~cm}^{13}$.

Kolesterol total, dalam serum darah yang dilakukan oleh analis di laboratorium RS Abunawas. Pengambilan sampel darah dilakukan saat subyek sedang berpuasa minimal 12 jam. Diperbolehkan minum air putih. Dilakukan $2 x$ kali yaitu sebelum intervensi dan setelah 4 minggu pemberian intervensi. Alat ukur yang digunakan yaitu spektrofotometer. Data akan dikategorikan kolesterol total (normal $<200 \mathrm{mg} / \mathrm{dL}$, tinggi $\geq \mathbf{2 0 0}$ $\mathrm{mg} / \mathrm{dL})^{14}$.

Asupan serat adalah jumlah rata-rata konsumsi serat harian yang diperoleh dari hasil konversi makanan yang dikonsumsi subyek perhari, yang diukur dengan food recall. Data dikategorikan menjadi dua yaitu kurang, jika rata-rata konsumsi 
lemak jenuh $<25 \mathrm{~g} /$ hari dan cukup, jika rata-rata konsumsi serat $>25 \mathrm{~g} /$ hari. Asupan lemak jenuh adalah jumlah rata-rata konsumsi makanan yang mengandung lemak jenuh yang diperoleh dari makanan yang dikonsumsi subyek dalam satu hari dibandingkan dengan AKG yang dianjurkan. Data dikategorikan menjadi dua yaitu cukup, jika rata-rata konsumsi lemak jenuh $<28 \mathrm{~g} / \mathrm{hari}$ dan tinggi, jika rata-rata konsumsi lemak jenuh $>28$ $\mathrm{g} /$ hari. Asupan kolesterol adalah jumlah rata-rata konsumsi makanan yang mengandung kolesterol dibandingkan dengan AKG yang dianjurkan, yang diperoleh dari asupan makanan dan minuman dalam satu hari. Data dikategorikan menjadi dua yaitu cukup, jika rata-rata konsumsi kolesterol $<300$ $\mathrm{mg} /$ hari dan tinggi, jika rata-rata konsumsi kolesterol $\geq 300 \mathrm{mg} /$ hari. Asupan energi adalah jumlah rata-rata konsumsi makanan yang mengandung energi (kal) yang diperoleh dari asupan makanan dan minuman dalam satu hari. Dibagi dalam kategori rendah, jika rata-rata konsumsi energi $<80 \%$ AKG normal, jika rata-rata konsumsi energi $\geq 80-100 \%$ AKG dan tinggi, jika rata-rata konsumsi energi $>110 \%$ AKG. Asupan lemak adalah jumlah rata-rata konsumsi makanan yang mengandung lemak jenuh yang diperoleh dari makanan yang dikonsumsi subyek dalam satu hari dibandingkan dengan AKG yang dianjurkan. Dikategorikan menjadi kurang, jika rata-rata konsumsi lemak <80-100\% AKG dan cukup, jika rata-rata konsumsi lemak $>100 \% \mathrm{AKG}^{15,16}$.

Sebelum digunakan alat ukur tinggi badan dan berat badan terlebih dahulu dilakukan kalibrasi oleh Badan Metrologi Daerah Istimewa Yogyakarta. Penelitian ini dilaksanakan setelah mendapatkan surat ethical clearance penelitian dari Komite Etik Penelitian Kedokteran Dan Kesehatan Fakultas Kedokteran Universitas Gadjah Mada dengan nomor surat KF/FK/30/EC/2016. Subyek penelitian terlebih dahulu diberikan penjelasan tentang latar belakang dan tujuan penelitian serta meminta kesediaan subyek penelitian secara sukarela tanpa paksaan apapun dengan menandatangani informed consent.

Data dianalisis menggunakan program Microsoft Excel 2007 dan StatalC 12. Analisis yang digunakan untuk membandingkan data profil lipid darah pada masing-masing kelompok sebelum dan sesudah intervensi adalah dengan menggunakan analisis paired t-test. Kadar lipid darah pada pengukuran sebelum dan sesudah dikatakan bermakna bila nilai signifikansinya kurang dari 0,05 $(p<0,05)$.

\section{HASIL DAN PEMBAHASAN}

Pada Tabel 1 memperlihatkan bahwa sebagian besar subyek berusia kurang dari 30 tahun sebanyak 45 orang sisa 21 orang berusia $>30$ tahun. Dari distribusi jenis pekerjaan, pada kelompok kontrol mendominasi mahasiswa sebanyak 11 orang kemudian diikuti ibu rumah tangga (IRT) 10 orang, wiraswasta 8 orang dan pegawai negeri sipil (PNS) 4 orang. Sedangkan pada kelompok intervensi mendominasi IRT sebanyak 10 orang kemudian mahasiswa 9 orang, wiraswasta 7 orang, (PNS) 5 orang dan tidak bekerja 2 orang. Berdasarkan hasil pengukuran antropometri, status gizi dengan parameter Index Massa Tubuh (IMT) pada kelompok kontrol dengan interpretasi tidak berisiko 22 orang dan yang berisiko 11 orang, sebaliknya pada kelompok intervensi berisiko lebih tinggi dari kontrol sebanyak 20 orang, dan yang tidak berisiko sebanyak 13 orang. Berdasarkan hasil analisis chi-square pada tabel di bawah untuk melihat perbedaan proporsi antara dua kelompok, dapat dilihat bahwa hanya status gizi dengan parameter IMT pada kedua kelompok berbeda secara signifikan, dimana hasil rerata pada status gizi dengan parameter IMT pada kelompok kontrol $22,72 \pm 3,80$ dan rerata status gizi dengan parameter IMT pada kelompok intervensi $23,96 \pm 4,53$. Sehingga perbedaan status gizi dengan parameter IMT pada kedua kelompok tersebut dapat menjadi faktor penganggu pada hasil analisis profil lipid selanjutnya. Sedangkan faktor yang lain seperti jenis kelamin, usia, pekerjaan, olahraga dan lingkar pinggang tidak berbeda antara kelompok kontrol dan kelompok intervensi.

Dari tabel 1 dapat dilihat bahwasanya sebagian besar kelompok kontrol memiliki aktivitas fisik atau olahraga yang rendah, lingkar pinggang dan status gizi dengan parameter IMT yang tidak berisiko. Sementara pada kelompok intervensi sebagian besar mempunyai aktivitas fisik atau olahraga yang normal, lingkar pinggang yang tidak berisiko tetapi pada status gizi dengan parameter IMT lebih ke subyek yang berisiko.

Tabel 1. Karakteristik subyek berdasarkan pekerjaan, lingkar pinggang, status gizi parameter IMT, dan aktivitas fisik

\begin{tabular}{ccc}
\hline \multirow{2}{*}{ Variabel } & \multicolumn{2}{c}{ Kelompok } \\
\cline { 2 - 3 }
\end{tabular}




\begin{tabular}{|c|c|c|c|c|c|}
\hline & \multicolumn{2}{|c|}{$(n=33)$} & \multicolumn{2}{|c|}{$(n=33)$} & \\
\hline & $\mathrm{n}$ & $\%$ & $\mathrm{n}$ & $\%$ & \\
\hline \multicolumn{6}{|l|}{ Jenis Kelamin } \\
\hline Laki-laki & 15 & 45,45 & 15 & 45,45 & \multirow[t]{2}{*}{ - } \\
\hline Perempuan & 18 & 54,55 & 18 & 54,55 & \\
\hline \multicolumn{6}{|l|}{ Usia } \\
\hline 20-30 tahun & 24 & 72,73 & 24 & 72,73 & \multirow[b]{2}{*}{ - } \\
\hline 31-40 tahun & 9 & 27,27 & 9 & 27,27 & \\
\hline \multicolumn{6}{|l|}{ Pekerjaan } \\
\hline Mahasiswa & 11 & 33,33 & 9 & 27,27 & \multirow{5}{*}{0,667} \\
\hline PNS & 4 & 12,12 & 5 & 15,1 & \\
\hline IRT & 10 & 30,30 & 10 & 30,30 & \\
\hline Wiraswasta & 8 & 24,24 & 7 & 21,21 & \\
\hline Tidak Bekerja & 0 & 0,00 & 2 & 6,06 & \\
\hline \multicolumn{6}{|l|}{ Olahraga } \\
\hline Normal & 15 & 45,45 & 17 & 51,52 & \multirow[t]{2}{*}{0,622} \\
\hline Rendah & 18 & 54,55 & 16 & 48,48 & \\
\hline \multicolumn{6}{|l|}{ Lingkar Pinggang } \\
\hline Tidak berisiko & 21 & 63,64 & 25 & 75,76 & \multirow[t]{2}{*}{0,284} \\
\hline Berisiko & 12 & 36,36 & 8 & 24,24 & \\
\hline \multicolumn{5}{|l|}{$\begin{array}{l}\text { Status Gizi } \\
\text { parameter IMT }\end{array}$} & \multirow{3}{*}{$\begin{array}{c}0,026 \\
*\end{array}$} \\
\hline Tidak Berisiko & 22 & 66,67 & 13 & 39,39 & \\
\hline Berisiko & 11 & 33.33 & 20 & 60.61 & \\
\hline \multicolumn{3}{|c|}{ Rerata $\pm S D$} & & $\mathbf{t}$ & $\mathbf{P}$ \\
\hline $\begin{array}{l}\text { Status Gizi } \\
\text { parameter IMT }\end{array}$ & \multicolumn{2}{|c|}{$22,721 \pm 3,80$} & \multicolumn{2}{|c|}{$\begin{array}{c}23,966 \pm 4,53 \\
-1,208\end{array}$} & 0,231 \\
\hline $\begin{array}{l}p \quad \text { dianalisis } \\
\text { signifikansi } p<0 \text {, }\end{array}$ & enge & nakan & uji & chi & uare, \\
\hline IMT: Indeks Ma & - & & & & \\
\hline
\end{tabular}

Gambaran kolesterol total sebelum intervensi (baseline data) dapat dilihat pada Tabel 2. Pada tabel ini menunjukkan bahwa tidak ada perbedaan signifikan antara kelompok kontol dan intervensi pada kadar kolesterol total. Untuk kadar kolesterol sebagian besar subyek baik kelompok kontrol maupun kelompok intervensi tergolong tinggi.

Tabel 2. Gambaran kadar profil lipid sebelum intervensi (Baseline Data)

\begin{tabular}{lccccc}
\hline & \multicolumn{4}{c}{ Kelompok } & \\
\cline { 2 - 4 } Variabel & \multicolumn{2}{c}{$\begin{array}{c}\text { Kontrol } \\
(\mathrm{n}=33)\end{array}$} & \multicolumn{2}{c}{$\begin{array}{c}\text { Intervensi } \\
(\mathrm{n}=33)\end{array}$} & $\mathrm{p}$ \\
\cline { 2 - 4 } & $\mathrm{n}$ & $\%$ & $\mathrm{n}$ & $\%$ & \\
\hline Kolesterol & & & & & \\
Total & & & & & \\
$\quad$ Normal & 10 & 30,30 & 6 & 18,18 & 0,251 \\
$\quad$ Tinggi & 23 & 69,70 & 27 & 81,82 & \\
\hline
\end{tabular}

Pada tabel 3 menunjukkan bahwa terdapat penurunan kadar kolesterol total yang bermakna untuk kelompk kontrol maupun kelompok intervensi $68 \mathrm{mg} / \mathrm{dL}$ vs $163 \mathrm{mg} / \mathrm{dL}$ ). Berbeda halnya untuk kadar
Tabel 3. Pengaruh intervensi terhadap kadar profil lipid

\begin{tabular}{|c|c|c|c|c|c|}
\hline \multirow{2}{*}{ Kelompok } & \multicolumn{2}{|c|}{$\begin{array}{c}\text { Profil Lipid } \\
\text { Rerata (min-max) }\end{array}$} & \multirow[t]{2}{*}{$\begin{array}{c}\text { Delta } \\
\mathrm{mg} / \mathrm{dL}\end{array}$} & \multirow[t]{2}{*}{$\mathrm{n}$} & \multirow[t]{2}{*}{$\begin{array}{c}\text { Nilai } \\
\mathrm{p}\end{array}$} \\
\hline & $\begin{array}{c}\text { Awal } \\
(\mathrm{mg} / \mathrm{dL})\end{array}$ & $\begin{array}{c}\text { Akhir } \\
\text { (mg/dLO }\end{array}$ & & & \\
\hline $\begin{array}{l}\text { Kolesterol } \\
\text { total }\end{array}$ & & & & & \\
\hline Kontrol & $\begin{array}{c}212 \\
(52-550)\end{array}$ & $\begin{array}{c}144 \\
(62-319)\end{array}$ & 68 & 33 & $\begin{array}{c}0.00 \\
*\end{array}$ \\
\hline Intervensi & $\begin{array}{c}356 \\
(52-730)\end{array}$ & $\begin{array}{c}192 \\
(103-399)\end{array}$ & 163 & 33 & $\begin{array}{c}0.00 \\
*\end{array}$ \\
\hline
\end{tabular}

Keterangan:

Data dinyatakan dalam rerata

$\mathrm{p}=\mathrm{uji} \mathrm{t}$ tidak berpasangan untuk variansi berbeda

*= nilai signifikansi $p<0,05$,

Kadar LDL,HDL,trigliserida dan kolesterol totaL disajikan dalam rerata (min-max)

Dari hasil penelitian menunjukkan tidak ada perbedaan kolesterol total berdasarkan jenis kelamin. Perbedaan hasil lipid tetapi tidak bermakna pada rerata kadar seluruh profil lipid antara kedua jenis kelamin ${ }^{11}$. Rata-rata responden baik laki-laki maupun perempuan memiliki kolesterol total, yang optimal. Kondisi ini sejalan dengan teori yang menyatakan bahwa pada rentang usia dua puluhan tidak terdapat perbedaan mencolok pada profil lipid laki-laki dan perempuan. Kenaikan yang tajam pada laki-laki baru dimulai pada usia tiga puluhan dan empat puluhan ${ }^{12}$.

Dari awal penelitian ini terlihat bahwa tidak ada perbedaan kolesterol total di usia 20-40 tahun. Kondisi tersebut sejalan dengan beberapa hasil penelitian yang menyatakan bahwa pada rentang usia dua puluhan tidak terdapat perbedaan mencolok pada koletsrrol total laki-laki dan perempuan ${ }^{12,13}$. Perbedaan profil lipid berkaitan dengan umur terhadap resiko CVD, mulai terjadi sejak usia muda (<40 tahun) dengan terbentuknya sel-sel busa dan berubah menjadi alur lemak (fatty streak) dan pada usia $>40$ tahun terbentuk kerak aterosklerosis ${ }^{17}$.

Pada pengukuran lingkar pinggang, sebagian besar kedua kelompok tidak berisiko. Tidak sejalan dengan hal ini, pernyataan lain menyatakan bahwa lingkar pinggang tidak signifikan secara statistik dengan perubahaan kadar kolesterol total. Lingkar pinggang yang melebihi ambang batas normal menunjukkan adanya penimbunan lemak dalam perut. Penimbunan lemak ini menyebabkan koleterol total menjadi naik ${ }^{14}$.

Berdasarkan hasil pengukuran antropometri, status gizi pada kelompok intervensi lebih berisiko dibandingkan dengan kelompok kontrol. Status gizi dengan parameter Index Massa Tubuh (IMT) signifikan mempengaruhi profil lipid. Penelitian lain 
yang sejalan dengan penelitian ini menyatakan bahwa status gizi dengan parameter (IMT) yang semakin meningkat berhubungan dengan meningkatnya kadar kolesterol ${ }^{15}$.

Analisis hasil pada penelitian ini menunjukkan bahwa untuk olahraga sebagian besar subyek kelompok kontrol dan kelompok intervensi tergolong rendah. Beberapa penelitian mengemukakan bahwa pemicu peningkatan kadar profil lipid (hiperlipidemia) disebabkan karena adamya penumpukan sel lemak dalam rongga perut. Olahraga dapat mendorong kebugaran tubuh yang berpengaruh terhadap pengeluaran energi dan mengurangi terjadinya penyakit kardiovaskuler ${ }^{16}$.

Asupan energi pada subyek penelitian ini adalah rendah pada kelompok kontrol maupun pada kelompok intervensi. Di Eropa, Cina, Asia Selatan dan Kanada, serta di Riyadh menunjukan bahwa semakin tinggi asupan energi maka semakin tinggi kadar kolesterol darah. Pada asupan lemak pun demikian bahwa orang yang mempunyai asupan lemak tergolong tinggi, memiliki risiko menderita hiperlipidemia 2,85 kali lebih tinggi dibandingkan yang mempunyai asupan normal ${ }^{17,18}$.

Pada hasil penelitian ini menunjukkan bahwa asupan lemak jenuh pada kedua kelompok tergolong asupan yang cukup. Berbeda dengan hasil pada penelitian ini, bahwasanya peningkatan asupan lemak jenuh juga meningkatkan kadar kolesterol total ${ }^{19,20,21}$.

Asupan kolesterol pada penelitian ini menunjukkan bahwa pada kedua kelompok tergolong asupan cukup. Berbeda dengan hasil pada penelitian ini, bahwasanya tingginya asupan kolesterol memicu peningkatan kadar kolesterol total ${ }^{22}$.

Hasil pada penelitian terhadap kadar kolesterol total menunjukkan penurunan yang signifikan pada kelompok intervensi 2,3 kali lipat dibandingkan pada kelompok kontrol. Penurunan kolesterol oleh pektin yang terkandung dalam jambu biji terjadi melalui mekanisme penghambat sintesis kolesterol oleh propionat sintesis kolesterol oleh propionat yang merupakan hasil fermentasi serat larut air didalam usus. Penurunan kolesterol juga dapat melalui pencegahan sintesis kolesterol terjadi pada tahap penghambatan enzim HMG-co A reductase. Enzim ini berperan dalam pembentukan mevalonat yang merupakan produk utama dalam pembentukan kolesterol. Dengan dihambatnya aktivitas enzim HMG-co A reductase maka tidak terbentuk mevalonat sehingga tidak terbentuk pula kolesterol $^{23}$

\section{SIMPULAN DAN SARAN}

Berdasarkan analisis hasil penelitian dapat disimpulkan bahwa pemberian terapi jus buah jambu biji dosis $400 \mathrm{mg}$ dalam bentuk sediaan 250 $\mathrm{ml} 1$ kali sehari, selama 30 hari dapat digunakan sebagai alternatif terapi untuk penurunan kolesterol total pada penderita dyslipidemia.

Hasil penelitian menunjukkan bahwa asupan serat dari jambu biji mampu menurunkan kolesterol total, maka perlu disosialisasikan manfaat jambu biji bagi penderita dislipidemia yang dapat berperan sebagai terapi non farmakologis.

\section{DAFTAR PUSTAKA}

1. Kemenkes RI. (2011). Strategi Nasional Penerapan Pola Konsumsi Makanan dan Aktivitas Fisik untuk Mncegah Penyakit Tidak Menular. Jakarta: Direktorat Jenderal Bina Gizi dan Kesehatan Ibu dan Anak.

2. Kemenkes RI. (2013). Riset Kesehatan Dasar (Riskesdas) Tahun 2013. Badan Penelitian dan Pengembangan Kesehatan. Jakarta: Kementrian Kesehatan Republik Indonesia.

3. Dinas kesehatan Provinsi SULTRA. (2013). Profil Tahunan Dinas Kesehatan Provinsi Sulawesi Tenggara Tahun 2013.

4. Dinas kesehatan Kota Kendari. (2013). Profil Tahunan Dinas Kesehatan Kota Kendari Tahun 2013.

5. Waspadji, S., Suryono, S., Sukarji, K.\& Kresnawan, S.A.T. (2010) Pengkajian Status Gizi. Jakarta: Balai Penerbit FKUI.

6. Krummel, D. (2004). Medical nutrition theraphy in cardiovascular disease. In: Mahan LK, Escott SS. Krause, Food, Nutrition and Diet Therapy. 11th ed. Pensylvania: Saunders.

7. Anwar, T.B. (2015). Dislipidemia Sebagai Faktor Resiko Penyakit Jantung Koroner.Thesis. Fakultas Kedokteran Universitas Sumatera Utara. 2004. Tersedia dalam <library.usu.ac.id> [Diakses 20 April 2015]

8. Guyton AC and Hall JE. (2004). Textbook of Medical Physiology, 11th edition, Elsevier Saunders. New York. USA: EGC.

9. Malvlya., Pranati., Rishabha, Srivastava. (2011). Sources of pectin, extraction and its application in pharmaceutical industry- an overview. Indian Journal of Natural Products and Resources. (2): 10-18

10. Mills, S and Bone, K. (2000). Principles and Practise of Phtochemistry Modern Herbal Medicine. Churchil Livingstone: Edinburgh.

11. Van Lennep, JER., Westerveld, HT., Erkelens, DW. Van der Wall, EE. (2013). Risk factors for coronary heart disease: implications of gender. Cardiovascular Research. 53: 538-549. 
12. Merchant, A.T., Anand, S.S., Kelemen, L.E., Vuksan, V., Jacobs, R., Davis, B., Theo, K., \& Yusuf, S. (2007). Carbohydrate intake and HDL in a multiethnic population. The American Journal of Clinical Nutrition. (85): 225-230.

13. Al-Ajlan, A.R. (2011). Lipid profile in relation to anthropometric measurements among college male students in Riyadh, Saudi Arabia: cross sectional study. International Journal Biomed Science.7(2):112-117.

14. Sartika, R.A.D. (2011). Faktor Risiko Obesitas pada Anak 5-15 tahun Indonesia. Jurnal Makara Kesehatan. 15(1): 37-43.

15. Tuminah, S. (2009). Efek Asam Lemak Jenuh dan Asam Lemak Tak Jenuh"Trans" terhadap Kesehatan. Gizi Indonesia. (1): 32.

16. Brown C.D., Higgins M., Donato K.A., Rohde F.C., Garrison R., Obarzanek E., Ernst N.D., Horan M. (2000). Body mass index and the prevalence of hypertension and dyslipidemia. Obesity research. (6): 605-69.

17. Terpstra AHM, Lapre JA, De Vries HT, Beynen AC. (2002). The Hypocholesterolemic Effect of Lemon Peels, Lemon Pektin, and the 21Waste Stream Material of Lemon Peels in Hybrid F1B Hamsters. Europan Journal Nutrition. 41: 19-26

18. Hernawati. (2007). Peranan Berbagai Sumber Serat dalam Dinamika Kolesterol pada Individu Hiperkolesterolemi dan Normokolesterolemi. Bandung: Jurusan Pendidikan Biologi Universitas Pendidikan Indonesia; Thesis. Bandung.

19. Yamasiro, S., Nougchi, K., Matsuzaki, T., Miyagi K. (2003). Cardioprotective effects of extracts from Psidium guajava $\mathrm{L}$ and limonuium wrightii, Okinawan medicinal plants, against iscemic-referfusin injury in perfused rat hearts. Pharmacology. (67): 128-135

20. Asmarantaka, Sutyarso, Wahyuni, A. (2013). Perubahaan Kadar HDL dan LDL Sebagai respon Latihan Aerobik Pada Aerobik dan Fitness Center Sonia Bandar Lampung. Thesis.

21. Almatsier, S. (2009). Prinsip Dasar Ilmu Gizi. Jakarta: PT Gamedia Pustaka Utama.

22. Rahmad, A., Abu, B. F. M., and Hambali, Z. (2006). The Effect of Guava (Psidium guajava) Consumption on Total Antioxidant and Lipid Profile in Normal Male Youth. African Journal of Food Agriculture Nutrition a development. 6(2): 1-12.

23. Fatimah., Maryanto S., Yustinus. (2004). Pengaruh pemberian jambu biji (Psidium guajava L) pada lipid serum tikus (sprague dawley) hiperkolesterolemia. Jurnal Media Medika Indonesia. 39(2): 10-16 